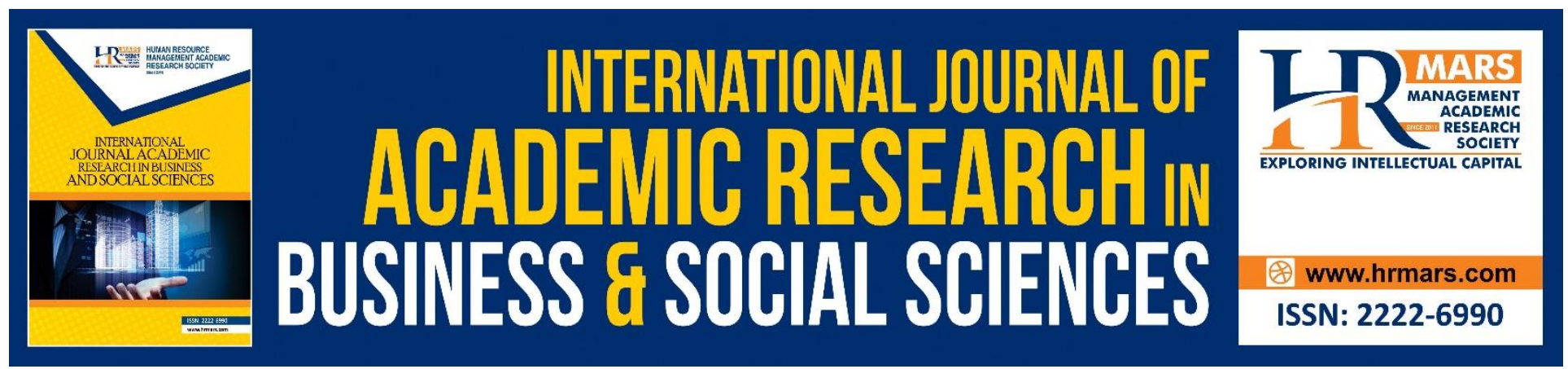

\title{
The Intention of Purchasing Power Towards Adidas Sportswear in Klang Valley, Kuala Lumpur
}

Smitha Geetha, Akram Abdulraqeb Sultan Al-Khaled, Chung Jee Fenn

To Link this Article: http://dx.doi.org/10.6007/IJARBSS/v10-i9/7719

DOI:10.6007/IJARBSS/v10-i9/7719

Received: 28 June 2020, Revised: 24 July 2020, Accepted: 22 August 2020

Published Online: 17 September 2020

In-Text Citation: (Geetha, Al-Khaled, Fenn, 2020)

To Cite this Article: Geetha, S., Al-Khaled, A. A. S., Fenn, C. J. (2020). The Intention of Purchasing Power Towards Adidas Sportswear in Klang Valley, Kuala Lumpur. International Journal of Academic Research in Business and Social Sciences. 10(9), 170-184.

Copyright: (C) 2020 The Author(s)

Published by Human Resource Management Academic Research Society (www.hrmars.com)

This article is published under the Creative Commons Attribution (CC BY 4.0) license. Anyone may reproduce, distribute, translate and create derivative works of this article (for both commercial and non-commercial purposes), subject to full attribution to the original publication and authors. The full terms of this license may be seen at: http://creativecommons.org/licences/by/4.0/legalcode

Vol. 10, No. 9, 2020, Pg. 170 - 1584

Full Terms \& Conditions of access and use can be found at http://hrmars.com/index.php/pages/detail/publication-ethics 


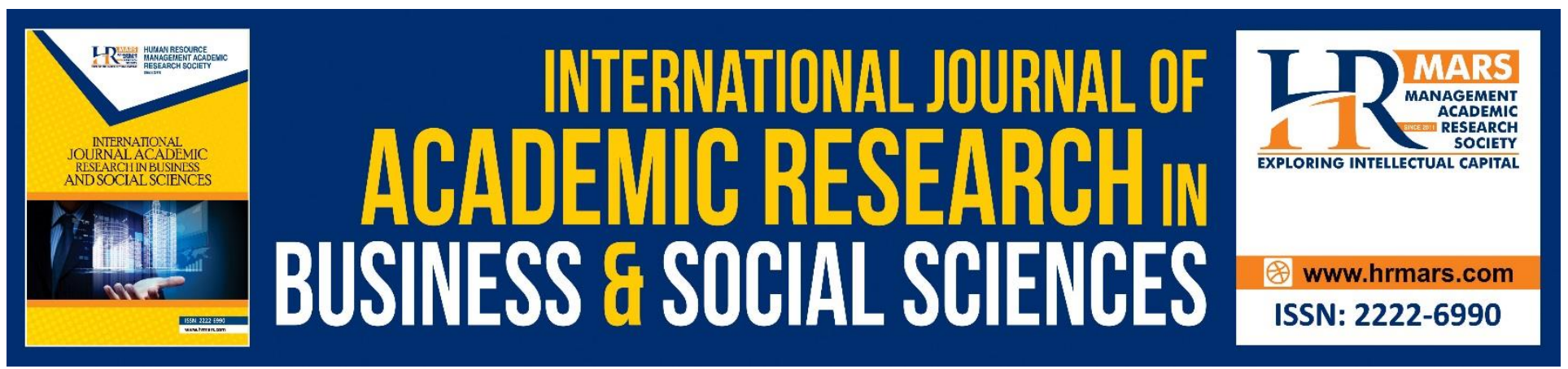

\title{
The Intention of Purchasing Power Towards Adidas Sportswear in Klang Valley, Kuala Lumpur
}

\author{
Dr. Smitha Geetha, Dr. Akram Abdulraqeb Sultan Al-Khaled \\ Faculty of Business, Berjaya University College, Malaysia
}

\author{
Assoc. Prof. Dr. Chung Jee Fenn \\ Centre of Institutional Research, Berjaya University College, Malaysia
}

\begin{abstract}
In any service industry and especially the Retail Industry, getting to know what influences the consumer's purchasing intention have become the main factor for companies to recognize in order to efficiently and effectively market their products to the market. As economic is changing, the factors that influence consumer's purchasing intention, it tends to change as well. That is why it is difficult to grasp what motivates them to buy. In Malaysia, the Retail Industry business have been growing and expanding as a lot of international brands are entering the Asia market to meet the needs and wants of different segment of customers. As such, the consumer's purchase intention has become more and more of an important factor for companies and brands to understand as there are a lot of competitors that would want to compete with similar customers, so knowing the customer's intention to purchase will give an advantage to the companies and brands. Therefore, this study is done in order to look for the most influential factors that motivate the consumer's purchase intention on Adidas sportswear in the area of Klang Valley, Kuala Lumpur. This study focuses on the factors that influence consumer's purchase intention on Adidas sportswear such as Celebrity Endorsement, Brand Personality and also Brand Image. The sampling that will be used in the study would be convenient sampling and a total of 200 respondents will be chosen randomly to assists with the study. Data collected will be analysed using Statistical Package for the Social Sciences AMOS (SPSS) and for the purpose of data analysis, Regression as well as Descriptive Analysis will be used.
\end{abstract}

Keywords: Purchase Intention, Celebrity Endorsement, Brand Personality, Brand Image.

\section{Introduction}

In the Sportswear market, more and more brands are trying to come out with greater ideas, introducing better technology to compete with some of the already well-established brand in the market, thus resulting higher consumer purchase intention. According to Department of Statistics Malaysia (2016), the average monthly household consumption expenditure in 2014 has increased from RM3,578 to RM4,033 in the year 2016, which have grew at 6.0 per cent per annum at nominal 
INTERNATIONAL JOURNAL OF ACADEMIC RESEARCH IN BUSINESS AND SOCIAL SCIENCES Vol. 10, No. 9, 2020, E-ISSN: 2222-6990 @ 2020 HRMARS

rate. According to the data collected, the main household consumption expenses; Water, gas. Electricity, housing \& other fuels (24.0\%) was the highest provider to the whole household intake expenses; Foods \& non-alcoholic beverages (18.0\%) placing second; followed by Transportation (13.7\%); and Restaurants \& hotels (13.4\%). Although the data shows increment of overall household expenditure, the Clothing \& footwear has a slight decrease in 2016 as compared to 2014. This shows that the consumer's purchase intention is unpredictable and can vary depend on the individuals. Today, the sportswear market is booming not just in the U.S, Europe and China, but in Malaysia as well as the current population of Malaysia as of Monday, January 22, 2018 is 31,857,605 based on the United Nations estimations (Worldometers, 2018). It has become a common yet popular piece for the consumer as it gives functionality and style at the same time, also known as athleisure. It is a very obvious trend to notice as we can see that giant brands like Adidas, Nike, Under Armour, Puma and so on are worn by young adults, teenagers and college kids especially.

\section{Research Background}

A recent trend in the Sportswear market has slowly become a norm and it can be seen in runways of high fashion. It has become a fashion staple that can be worn in our everyday lives, and not only during sports activity, which now it is called the Athleisure. According to a professor of history at the University of Nevada in Vegas, Clemente, (2017) Athleisure is the new casual, as it is now evolved with the combination of business casual and sportswear into one. In today's time, people want products or items that are less maintenance as they just do not have the time to do so, that is why athleisure is a big hit as who doesn't want to look good and feel comfortable at the same time. That is why consumers are interested in buying sportswear. In the early 90's, sportswear were designed and sold only to woman, made by two prominent Parisian tennis player, Jane Regny and Suzanne Lenglen. As they were often associated with country clubs and aristocrats, the tennis wear has been steadily referenced since the 1920s, and because of that, brand such as Fred Perry had reached out to them, to emerge themselves with the prep styles of British Mod subculture. As a result, Fred Perry's athletic roots have turned into a $100 \%$ street fashion. Back then, Adidas was not in their best position yet as they did not expect the sportswear industry changed so much. After the Superstar era, they failed to replicate the success even if the demand for athletic gear are booming, and because of that the underdog, Under Armour have surpassed Adidas's sales by $20 \%$ (The Telegraph Business, 2016) Thing took a turn when the creative director of Adidas, Paul Gaudio studied their competitor, Nike and outlined a mission for the whole company, targeting more customers that is trend-savvy rather than the style-agnostic sports enthusiasts that they had always relied in the past.

Before Adidas even become a global fashion piece, they were known for its technology that helps athletes to perform better in sports. In 2013, Adidas has created a new innovative cushioning system that helps provide its consumers the highest energy returns in all the running shoes, Adidas Boost. It has become the key factor that provide the consumers a comfortable wear for long-distance walks or runs, and this system are now being used in all the Adidas line including the basketball sneakers, football cleats, lifestyle sneakers and even the modernized classic shoes like the Superstar (Business Insider, 2017).

Because of that innovative image, it has influence consumes to make decision on which brand they would like to purchase. As mentioned by Wang and Tsai (2014), during the course of making a decision during purchasing process, Brand Image is an important cause that will motivate the consumer. Mara Leighton, a commerce reporter shows satisfaction after he purchased the Adidas 
INTERNATIONAL JOURNAL OF ACADEMIC RESEARCH IN BUSINESS AND SOCIAL SCIENCES Vol. 10, No. 9, 2020, E-ISSN: 2222-6990 @ 2020 HRMARS

Ultra Boost X, claiming that, "I trust Adidas when it comes to great running shoes. Not only are they sustainable and look great with anything, but they also have Adidas' Boost technology which makes them really, really comfortable" (Business Insider, 2017).

Fast forward to 2018, Adidas have already conquered both the sports and fashion industry, whereby they have form a collaboration with the infamous rapper, Kanye West, the artists; Pharrel, Raf Simons, David Beckham as well as other more celebrities and supermodels such as Gigi Hadid and Kendall Jenner. In addition, because of that, Adidas have outshined Under Armour, who is struggling at that time and reclaim its throne as the No 2 spot in North America (Business Insider US, 2017). As (Khan, Rukhsar, \& Shoaib,2016) mentioned: "Multinational organization used celebrity endorsement in the advertisement as they believed the celebrities will bring in positive impact for consumer buying behaviour and their purchase intention".

\section{Problem Statement}

Like consumers in the US and Europe, the Chinese buyers are slowly increasing the love for sportswear as a daily outfit. Colin Currie, Adidas's Managing Director for Greater China (Quartz, 2017) mentioned that the Chinese buyers are into pieces that they are able to wear for social events as well as sports too. She even said that in the lower cities of China, it is fine to attend a wedding or go to work in Adidas. Based on the Nike Inc. Reports Fiscal (2017), there is a recorded growth of about $9.5 \%$ whereas for Adidas, their Annual Report (2016) stated that their sales went up to $22 \%$ in 2015 . This shows that the sportswear market can be bigger if the sportswear brands play the right card as the consumer's needs and wants changes all the time. It is worth for us to understand the purchase intention of this popular sportswear culture in Malaysia as well.

The sportswear market has never been bigger. In China, the sportswear market is already massive but it is only getting bigger. The demographics in China have over 415 million millennial, and they have the world's biggest middle class segments and the number does not stop there. (Quartz, 2017). According to the research firm, Euromonitor (2017) the sales for sportswear in China have escalated $11 \%$. By looking at the growth of sportswear market in China, US and Europe that contributes to the trend of athleisure, there is a high possibility that the Malaysian will follow this trend as there is a proven high demand for sportswear all over the world, and how would the local brand compete with this popular brand, Adidas?

Nowadays, consumers are over-exposed to technology especially social media. An individual who is living in a over populated country are exposed to one thousand advertisements on average per day but they would tend to forget $80 \%$ of the information within 24 hours (Nyarko, Asimah, Agbemava \& Tsetse, 2015). To overcome this problem, company of all brands will endorse a celebrity so that they are able to convey their message loud and clear to consumers consider that celebrity are able to reach out to more people than just traditional advertising marketing. So, one of the study is to find out if celebrity endorsement is truly one of the factor that could influence the consumer's intention to purchase.

Giant sportswear brand such as Adidas, Nike, Under Armour, Puma and so on, are on top in their industry, more so when they collaborate with celebrities such as Kanye West, Pharrel Williams, Gigi Hadid and much more. In Malaysia, there are some local brands that are quite known for its wide array of sportswear apparels and most importantly for their quality and reasonable price as well such as MOVE by Twenty3, Ultron, Liberty Active, FitGear, Fit Rebel as well as Ash Be Nimble (Ng, 2017). So why do Malaysian only purchase giant brands sportswear such as Adidas, Nike, Puma and so on, 
INTERNATIONAL JOURNAL OF ACADEMIC RESEARCH IN BUSINESS AND SOCIAL SCIENCES

Vol. 10, No. 9, 2020, E-ISSN: 2222-6990 @ 2020 HRMARS

instead of the local sportswear brands? Do local brands sportswear do not have the chance to compete with them?

\section{Research Objectives \\ Main Objective}

This is to study the purchase intention towards Adidas sportswear in Klang Valley, Kuala Lumpur.

Sub Objectives

1. To identify the factors that influence consumer's purchase intention.

2. To identify which factors is the most influential on consumer's purchase intention.

\section{Research Questions}

1. Is there a relationship between purchase intention and celebrity endorsement?

2. Is there a relationship between purchase intention and brand personality?

3. Is there a relationship between purchase intention and brand image?

\section{Research Hypotheses}

1. There is a relationship between purchase intention and celebrity endorsement.

2. There is a relationship between purchase intention and brand personality.

3. There is a relationship between purchase intention and brand image.

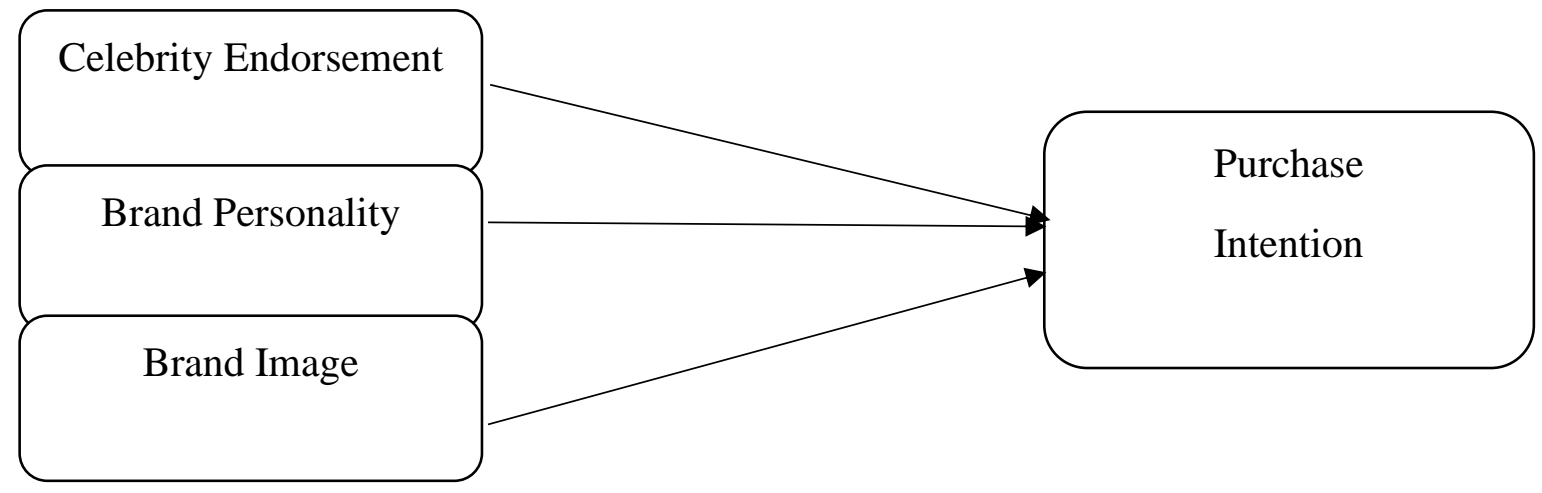

Figure 1: Conceptual Framework

\section{Literature Review}

Purchase Intention

In any service industry, understanding the consumer's purchase intention is important as it helps the company to rule out the causes that encourage the behaviour and use that statistics to for their advantage. Customers will expect to purchase a product when a certain factor triggers it, stated by Wang and Tsai (2014) is called Purchase Intention. The author (2014) then goes on and said, "The bigger the will to purchase a product, the greater the chances of purchasing it, but that does not mean that people will actually buy it". The term described by Crosno, Freling \& Skinner (2009) is the possibility of buying a unique brand in a category of product during purchasing process. Of course, the application of consumer's purchase intention depends on various reasons which could be their willingness and interest to the product (Ling et al., 2010). 
Many studies have shown that there will be a higher purchase intention towards a brand if the company increases their value of services or products, which also depending on various reasons as mentioned above. The theory of reasoned action (TRA) proposed by Fishbein and Ajzen (1975) is commonly used in the consumer behaviour literature and purchase intention studies (i.e. Alsughayir \& Albarq, 2013; Beadnell, Baker, Gillmore, Morrison, Huang \& Stielstra, 2008). Vahdati and Nejad (2016) proposed that the TRA theory is assuming a particular individual's intention to execute the behaviour as a function of 1 . the individual's behaviour in a situation; 2 . the norms that oversees the behaviour in a particular situation and the motivation behind these norms (subjective norms). Since this term is very practical and instrumental where the individuals are personally responsible for their intention to purchase, this is why researchers such as Hakkak, Vahdati \& Mousavi (2015) used this framework to study the consumer's intention to purchase in areas like bank.

Purchase intention also represents the possibility of consumer's planning or willing to purchase a certain product or service in the future, meaning it will increase the chances of the possibility of that certain products or services to be bought (Wu et al., 2011). It can also meant as the composed of consumer's feelings, thoughts, experience and external environment that he considered before making a purchase according to AsimTanvir and Mariam (2012). In other words, that is why a lot of company or brands study on purchase intention, to collect the valuable information, evaluate alternatives as well as making purchase decision in the process of buying, as it is an important indicator to estimate and predict the consumer's behaviour (Chi et al., 2011)

Moreover, another study has shown that the purpose to purchase could be acknowledged as a mirror image of true buying behaviour. Nasermoadeli, Ling and Maghnati (2013), believed that the greater the intention to purchase, the greater the one's desire to buy the products or services. Chi, et al (2009) appealed that there will be a possibility of changes of customer's purchase intention as well as their preference if the right marketing strategy is used. Also, Fournier (1998) learned that consumer will feel the appreciated and of important asset to the company, if that particular company or brand provides particular features that meets their needs and wants, and slowly the consumer will then form a bond with the brand, thus increase the chances of their intention to purchase. That is why, purchase intention would be considered as an important variable to evaluate the factors (celebrity endorsement, price, brand image, brand personality and brand loyalty) that influence the consumer.

\section{Celebrity Endorsement}

Friedman and Friedman (1979) specifically describe celebrity advocate "as an individual who is wellknown by the public for his or her success in parts other the endorsed products". A celebrity advocate is also described as "any individual who appreciates public acknowledgement and uses this success to appear on advertisement and endorsed consumer goods on behalf of the company" studied by McCracken (1989). Many brands are working together with public figure or also known celebrity to endorse their products so that it gives a popularity, more media coverage and recognition for the sole purchase of purchase motivation, than using traditional marketing advertisement (Jain \& Roy, 2016).

According to Nyarko, Asimah, Agbemava and Tsetse (2015), they studied on the research of Kotler and Armstrong (2000), and have agreed that endorsement is a network of brand communication where a personality will represent the brand plus testify the claim that the brand has made to the public, by utilising his or her character, fame, as well as status in the public. Since a celebrity is a 
INTERNATIONAL JOURNAL OF ACADEMIC RESEARCH IN BUSINESS AND SOCIAL SCIENCES Vol. 10, No. 9, 2020, E-ISSN: 2222-6990 @ 2020 HRMARS

person that the society looked up to, they definitely have an influence on the consumer's buying intention, as they will believe in what the celebrity they looked up to endorsed. That is why company will carefully select who will be the ambassador for their brand, as what a public figure do will reflect the image of the brand.

When a celebrity has a positive image in the public eye, it will result in a positive outcome for the company as the sales will increase. The consumer might be willing to buy the product because their favourite celebrity endorsed it, might not be because they think the product is good, as mentioned by Chaudhary and Asthana (2015). Chan, Ng and Luk (2013) agreed with the research by stating that public campaign run by celebrity endorser will have the ability to improve the image of the company's brand, therefore influence the intention to purchase. They also continue to note that if the sales of a particular services or product will decrease if the celebrity endorser is involved in a negative situation that will jeopardise the image of the brand and vice versa. How a celebrity acts in front of the public eyes will portray the image of the brand, that is why company would want to hire celebrities has the charm and attractiveness to endorse their brand and avoid scandalous celebrities as much as possible (Sääksjärv, Hellen, Balabanis, 2016). A celebrity, who will act as a spokesperson once the company want him or her to represent the brand, they will of course provide testimonial about the benefit of consuming the products or services (Leonidou, Hadjimarcou, Kaleka, Stamenova, 1999). First impression is always the key to attract the attention of somebody, so often marketers will select celebrity endorsers who are attractive, trustworthiness, expertise as well as the correlation amongst the brand image and the image of the celebrity himself (Dissanayake and Weerasiri, 2017).

The author also mentioned that a physically attractive celebrity endorser is able to improve a brand's image and at the same time them to purchase that brand. What's more, if the marketers look for celebrity with knowledge and expertise as well, it will also increase the chances of intention to purchase. Even though trust is important to form a relationship between one brands to the consumer but according to Aziz (2013), "“The trustworthiness of the celebrity is a supportive element underlying source of credibility, but research has shown that it is not a factor in increasing consumers' intention to try a brand". Therefore, hypothesis is concluded:

H1: There is a positive relationship between celebrity endorsement and consumer's purchase intention.

\section{Brand Personality}

Zenker and Braun (2017) defined brand as a "sign, name, term, design, symbol and or mixture of all of them which is proposed to recognize the goods and services of one or more group of seller so that consumers are able to distinguish themselves from their rivlas". Maehle et al., (2011) explained that the concept of personality of a brand is recognizing the use of human descriptors to describe a brand. Plummer (2000) further clarified that the interaction between the consumer and the brand, whether it is direct or indirect will create and influence the perceptions of the personality traits of the brand. According to Nhat et al. (2012), the definition of brand personality is "the set of human characteristics that associates with the brand". From the author's explanation, Su and Tong (2015) believed that brand personality will enable consumers to recognize themselves with the brand and they will be able to express their own characteristics and personality through the brand.

Aaker (1997) had developed a theoretical framework which is the five-factor model of the personality of the brand, and this theory was centred on the five big personality qualities outline of openness, conscientiousness, extraversion, agreeableness and neuroticism that originated from a psychology 
INTERNATIONAL JOURNAL OF ACADEMIC RESEARCH IN BUSINESS AND SOCIAL SCIENCES Vol. 10, No. 9, 2020, E-ISSN: 2222-6990 @ 2020 HRMARS

discipline. The author developed a framework model that will be easy to measure using a generalizable scale, which is sincerity, excitement, competence, sophisticated, and ruggedness according to the framework mentioned above. Quite a number of research have used this theory to branding research (Sung and Kim, 2010; Kim et al., 2001) and most of the research found that the brand personality most definitely will influence the information processing, levels of consumer trusts, brand affect as well as increasing brand loyalty. Eisend and Stokburger-Sauer (2013) had conducted a meta-analysis and found out that the consumer's purchase intention, brand attitude, image as well as commitment will be influence by brand personality.

However, there are numbers of studies that have proved the model in recent years. Based on Azoulay and Kapferer (2003) research, he argued that some of the definition for brand personality by some authors are inaccurate as it consists of other brand qualities such as age and gender, and in his opinion does not really related to personality. Another author, Austin (2003) argued that the model developed by Aaker (1997) are inaccurate as well because "it was established based on betweenbrand variance that produces great worries on the factor structure for analysis" for a specific brand at a respondent. Since the basic model could not identify which brand personality is more effective than the other, Freling et al. (2011) had piloted a concept and developed researches to identify consumer's perception on the appeal of the personality of the brand.

Freling et al. (2011) had established a theory that measures the Brand Personality Ability (BPA), which is the capability of a brand to attract to buyers through its personality qualities. According to the author, BPA is define as, "a brand's capability to attract buyers through the mixture of human characteristics". BPA also measures the influence of the brand's personality on the attitudes and behaviour of the consumers (Freling et al., 2011). Gordon et al. (2016) support the study when Freling et al. (2011) mentioned that this knowledge will be able to assists managers' understanding of the importance and durability of a BP and how it will influence the attitudes and behaviour of the consumers.

There are three factors in the BPA theory that Freling et al. (2011) had developed, i.e. favourability, originality and clarity. For the favourability factor, it allows assessment on whether the brand's personalities perceived by consumers are positive and able to provide fulfilment which will lead to a more positive assessment during the consumption of the brand but, the author did also predict that there may be some consumers who will not be able to distinguish the brands without perceiving a number of brands in the market. Thus, Freling et al. (2011) stated that, "favourability alone is not adequate enough for a BP to attract buyers".

The second factor, originality is well-defined as, "the degree to which buyers identify the brand's personality to be distinctive and different from other brands in the market" (Freling et al., 2011), which basically means the consumers have a purpose of purchasing one brand over the other according to Keller (1993). While both favourability and originality in BP are vital, but it is not sufficient enough for the target audience to notice the brand's personality. So, the final factors to complete the BPA theory would be the clarity, which the brand's personality have to be portray and easily recognizable to the target buyers (Freling et al., 2011). The BPA theory studied by Gordon et al., (2016) mentioned that understanding consumer's perceived on brand personality is based on the Fishbein and Azjen's (1975) expentancy-model, which the theory back then would only partially evaluate the factors that influence BP centred on philosophies about the traits of the entity. Based on Freling et al. (2011) study, there is a direct positive influence on buyer's buying intention with the favourability as the highest influence, followed by originality and clarity. 


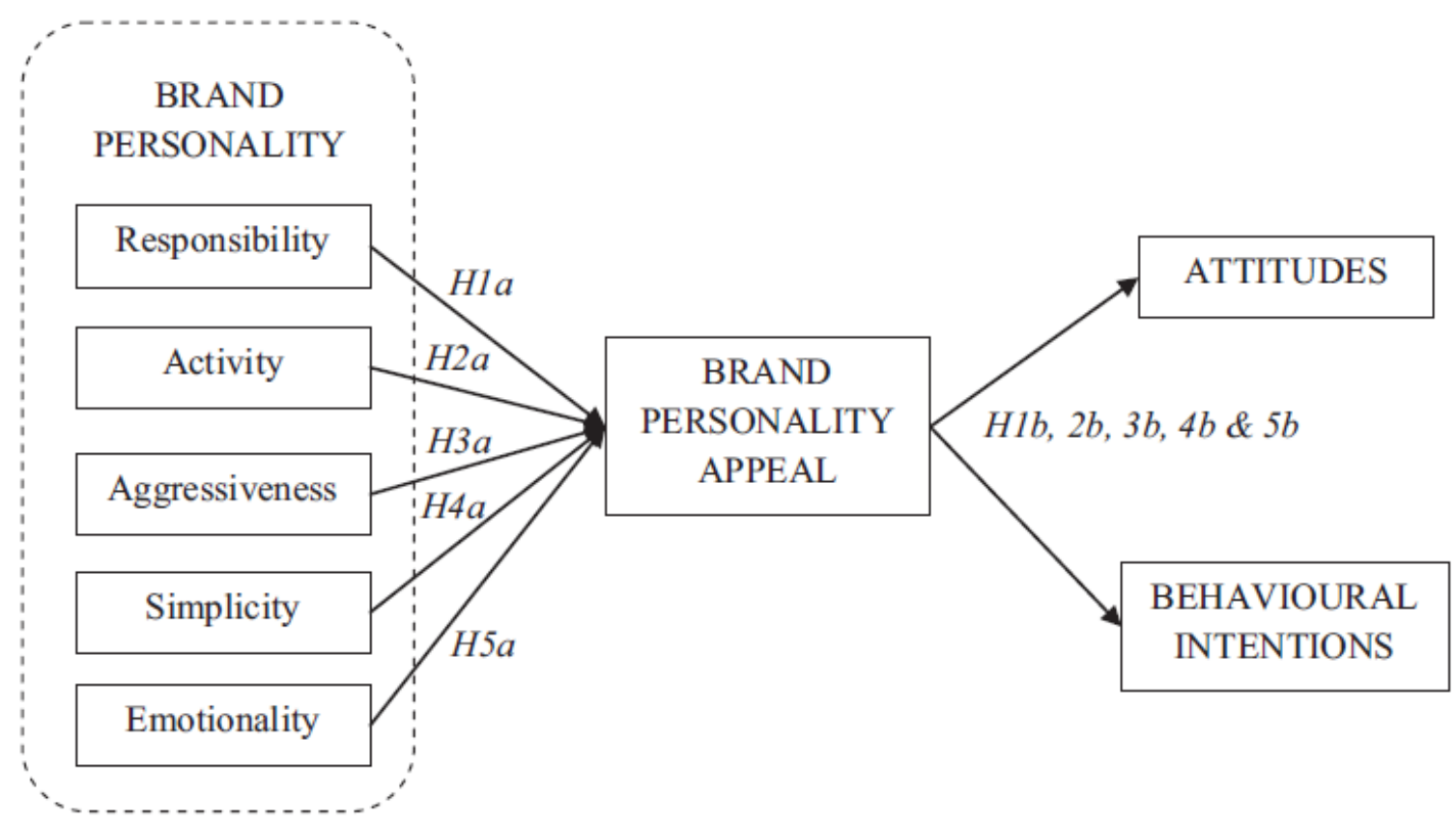

Figure 2: Theoretical model testing for BPA

Source: Gordon, R., Zainuddin, N., \& Magee, C., (2016); Unlocking the potential of branding in social marketing services - utilizing brand personality and brand personality appeal

Centred on the theoretical model studied by Freling et al. (2011), it shows that BP has a straightforward relationship with BPA, and BP has an indirect relationship with attitudes and behavioural intentions in social marketing as well as commercial marketing services. Overall, the author has confirmed that there is a positive impact on purchase intention based on the brand's personality. Thus, the hypothesis is concluded:

H2: There is a positive relationship between consumer's purchase intention and brand personality.

\section{Brand Image}

Brand image have long been known as an important factor in the concept of marketing and from consumer's point of view, it acts as a type of information that not only affects overall image of the company but also a motivator for the consumer's purchase intention (Keller, 1993). The author stated, "Brand image is a perception of a product in which it reflects the customer's memory in the product". The author continued, saying the consumer due to subjective reasons and their own personal emotions only assumes the concept of the brand image. Besides, a positive brand image can benefit the company in a long run, as that is what the consumer's remember in their memory (Fianto, 2014).According to Fianto (2014), a good choice of brand name can help a company to have the ability to be distinctive (differentiability), brilliant (intensity) and trust that were associated with the brand. When consumers wanted to purchase products, they are expressing brand awareness and brand association and therefore assuming the quality of the product, which then affects their purchase intention (Chao, 2015). The factors that help form the image of the brand in terms of brand 
association would be the presence of brand association (Keller, 1993). Brand associations describes the characteristics of the consumer's trust and benefits provided, that will be able to satisfy the needs and wants of the consumer so that the consumers will be able to form a positive behaviour towards the brand (Zhang, 2015). It will be increasingly difficult for competitors to compete with the brand if the strength of brand association of that particular brand is strong and unique (Hussain et al, 2012). If so, this will create a competitive advantage, and the more reason for consumers to choose the brand.

According to Farida and Ardyan (2015), what consumers have in mind of brand image is that it sees the promises of what the brand has made and from those perspectives, it creates personal characteristics of the brand's product in their mind. Many studies have confirmed that, company will be expecting a positive purchase intention from consumers if they continued to build a positive brand image (Chang \& Fong, 2010). Hsieh (2016) justified Chang and Fong's (2010) statement by saying that when the consumer is gathering information on the product, the image of the brand will influence the perception of the brand. During the gathering of information process, not only would consumer considered the quality but also the image of the brand, as mostly they would only intent to buy it when they know the brand has a good reputation. Therefore, hypothesis is as follow:

H3: There is a positive relationship between brand image and consumer's purchase intention.

\section{Research Methodology}

Research Method Design

Quantitative research will be done in the research methods. The terms of the quantitative approach are to be able to categorized with descriptive methods, correlation of research, and the causal comparative research and also experimental research. Therefore, all the data collection analysis has to have survey from the consumer who has owns a / some Adidas sportwears in Klang Valley, Kuala Lumpur

This research is designed to be able to help the managerial level to understand better on consumer's intention to purchase in the Service Industry. This research will also help managerial level to understand their target consumer and maximize their target market in Service Industry.

\section{Population of the Target Market}

According to the Department of Statistics Malaysia (2017), the population in Malaysia as of $14^{\text {th }}$ July 2017, is at estimated of 32.0 million with 28.7 million are citizens and 3.3 million that are non-citizens. Out of the 32.0 million citizens, $69.7 \%$ of it is aged between $15-64$ years old. That shows that, half of the millions of citizens in Malaysia might have the chances to own a pair / some Adidas sportswear since they have more buying power than teenagers, aged 0-14 years, that is only $24.1 \%$ out of the total number. With these target market, it will assists me with my research study as I will be able to find out a more accurate result on the factors that influence their purchasing intention on Adidas sportswear.

\section{Data Analysis}

The demographic data will be displayed in the form of pie chart whereas the variables will be in the form of bar chart, which could clearly show the proportions of the numbers of responses. This is mainly to display the analyzed data, collected from the target respondents in order to make a final result for this research. 
INTERNATIONAL JOURNAL OF ACADEMIC RESEARCH IN BUSINESS AND SOCIAL SCIENCES Vol. 10, No. 9, 2020, E-ISSN: 2222-6990 @ 2020 HRMARS

For the research demographic and variables data analysis, Frequency Distributions Analysis will be used to identify the findings from the data collected, in order to obtain information about respondent's age, gender, income level, occupations, as well as their level of purchase intention on different factors. Data that are collected will be analyzed using SPSS.

There also will be ANOVA, correlation analysis and descriptive analysis. In the survey questionnaire that will be distributed, the purpose is to find out from the respondents, which key factor makes them to have purchase intention towards Adidas sportswear in Klang Valley, Kuala Lumpur.

\section{Research Strategy}

I would want to go for a more convenience sampling methods whereby online questionnaire will be created and distributed to 150 respondents who have own a pair / some Adidas sportswear in Klang Valley, Kuala Lumpur. Besides, quantitative research method will be used to collect data as well, thus data collected will be analyzed with number in SPSS. The targeted market will be age 15 and above.

\section{Results, Findings and Discussion \\ Conclusion and Recommendation}

As millennials are the people who have a higher potential in purchasing online in social commerce, thus identifying the factors of their online purchase intention, it can help the sellers to target them and re-enhance the consumers' confidence toward the online purchasing in social commerce. There are three objectives of this study which are to determine what are the factors will influence consumers' online purchase intention, which the factors included trust, perceived ease of use and perceived usefulness. Therefore, the dependent variable is consumers' online purchase intention, whereas trust, perceived ease of use and perceived usefulness are the independent variables in this research. In this research, it provided insight for consumers' online purchase intention and its influences. The results enable the sellers to focus on the factors that will stimulate the online purchase intention of the consumers in social commerce. There were some decision would be suggested in order to gain back the confidence from the consumers towards social commerce and online purchasing as well as to ensure the sellers to meet the requirement of consumers. First of all, the vendors or sellers in social commerce needs to avoid fraud all the time. This is because the consumers' trust would lose once it was a fraud on them. The result of the study stated that trust has a significant impact on consumers' online purchase intention. In order to enhance the consumers' trust, the sellers should deliver the products on time, and make sure all the consumers' private and personal information is not revealed. The sellers need to encourage the buyers and users sharing their feedback and review after purchasing the products in social commerce platform. By doing so, the sellers can able to make the adjustment or improvement based on review and feedback given. If the consumers aware of the seller's changes or improves, it helped to enhance the consumers' trust because the sellers are finding a suitable way to meet the consumers' requirement and satisfaction. When the trust is gradually increasing, it means that the consumers' online purchase intention will also get higher. The second factor was perceived ease of use, this factor has the highest effect on consumers' online purchase intention. The sellers or vendors should design a clean and simple website. People tend to pursue a purchase platform that is easy to learn and use, has a clear direction and function as well as convenience. The sellers can be conducting the activity in social media, which guides the users on how to use in term of searching and purchasing the products. By doing so, it not only provided a clear direction to the users in term of online purchasing but only helped to build trust 
among the users and increased the sales. The third factor was the perceived usefulness. The sellers need to first provide value to the consumers, then only can able to attract the consumers to purchase the products from the sellers. For example, the features of the purchasing website must have the keywords of searching in which allow the users to rapidly acquire the information about the products. It is vital of the website features as if the features of the websites are not helpful and useful to them, it leads to the decreasing of their purchasing interests and the switch the selection of purchasing the product to the competitors.

There were few limitations occurred in this study, it could enable the researchers to solve the limitation for the future. First, the limitation of this study is the distribution for the survey questionnaire, mostly are the respondents in Klang Valley and Ipoh. This study aims to the whole Malaysian, but the respondents that distributed mostly are these two cities. There are only 387 respondents in this study, therefore the researchers in future can able to enlarge the respondents amount For future research, the researchers need to spread each of the city in Malaysia such as Penang, Kedah and other states in Malaysia, at the same time increase the respondents amount for distribution the questionnaire. Apart from that, the way for distributing the survey questionnaire was just through the online method. This is because there are higher chances of the invalid data by distributing the survey through online as some respondents may not understand the topic clearly. Therefore, the research can try to another way of distribution in order to make the data more reliable and valid, such as a face-to-face survey. On the other hand, this study only focused on the three factors that influence consumers' online purchase intention. It could be one of the limitations as there may have others factor that can influence the dependent variable. By exploring the other factors, the researchers can able to understand more detail that can influence the dependent variable, other than the three factors. For example, the researchers can explore the factors of security, in order to determine whether there was an influence on consumers' online purchase intention or not.

\section{References}

Adler, J., \& Parmryd, I. (2010). 'Quantifying Colocalization by Correlation: The Pearson Correlation Coefficient is Superior to the Mander's Overlap Coefficient', International Society for Advancement of Cytometry, vol.77A, pp.733-742.

Ajzen, I. (1991). 'The theory of planned behavior', Organizational Behavior and Human Decision Processes, vol.50, no.2, pp.179-211.

Ali, H. (2011). 'Exchanging value within individuals' networks: Social support implications for health marketers', Journal of Marketing Management, vol.27, no.3-4, pp.316-335.

Barkhi, R., \& Wallace, L. (2007). 'The impact of personality type on purchasing decisions in virtual stores', Information Technology Management, vol.8, pp.313-330.

Burns, A., \& Bush, R. (2014). Marketing Research $7^{\text {th }}$ Edition, Pearson, United States.

Cheng, B. L., \& Yee, S. W. (2014). 'Factors Influencing Consumers' Online Purchase Intention: A Study among University Students in Malaysia', International Journal of Liberal Arts and Social Science, vol.2, no.8, pp.121-133.

Cheng, X., Gu, Y., \& Shen, J. (2018). 'An integrated view of particularized trust in social commerce: An empirical investigation', International Journal of Information Management, vol. 45, pp. 112. 
INTERNATIONAL JOURNAL OF ACADEMIC RESEARCH IN BUSINESS AND SOCIAL SCIENCES

Vol. 10, No. 9, 2020, E-ISSN: 2222-6990 @ 2020 HRMARS

Chui, Y. B., Lin, C. P., \& Tang, L. L. (2005). 'Gender differs: Assessing a model of online purchase intentions in e-tail service', International Journal of Service Industry Management, vol.16, no.5, pp.416-435.

Curty, R. G., \& Zhang, P. (2013). 'Website Features that Gave Rise to Social Commerce: A Historical Analysis', Electronic Commerce Research and Applications, vol.12, no. 4, pp.260-279.

Davis, F. (1989). 'Perceived Usefulness, Perceived Ease of Use, and User Acceptance of Information Technology', MIS Quarterly, vol.13, no.3, pp.319-339.

Delafrooz, N., Paim, L., \& Khatibi. (2011). 'Understanding consumer's internet purchase intention in Malaysia', African journal of business management, vol.5, no.3, pp.2837-2846.

Featherman, M., \& Pavlou, P. (2003). 'Predicting e-services adoption: a perceived risk facets perspective', International Journal of Human-Computer Science, vol.59, no.4, pp.451474.

Ghasemi, A., \& Zahediasi, S. (2012). 'Normality Test for Statistical Analysis: A Guide for NonStatisticians', International Journal of Endocrinology and Metabolism, vol.10, no.2, pp.486-489.

Gogtay, N. J., Deshpande, S. P., \& Thatte, U. M. (2017). 'Principles of Regression Analysis', Journal of the Association of Physicians of India, vol.65, pp.48-52.

Hajli, N. (2015). 'Social commerce constructs and consumer's intention to buy', International Journal of Information Management, vol.35, pp.183-191.

Hajli, N., Sims, J., Zadeh, A. H., \& Richard, M. O. (2017). 'A social commerce investigation of the role of trust in a social networking site on purchase intentions, Journal of Business Research, vol.71, pp.133-141.

Hauke, J., \& Kossowski, T. (2011). 'Comparison of Values of Pearson's and Spearman's Correlation Coefficients on the Same Sets of Data', Quaestiones Geographicae, vol.30, no.2, pp.8793.

Hawes, J., Kenneth, M., \& Swan, J. (1989). 'Trust Earning Perceptions of Sellers and Buyers', Journal of Personal Selling and Sales Management, vol.9, no.1, pp.1-8.

Heale, R., \& Twycross, A . (2015). 'Validity and reliability in quantitative research', Evidence-Based Nursing, vol.18, no.3, pp.66-67.

Hew, J. J., Lee, V. H., Ooi, K. B., \& Lin, B. S. (2016). 'Mobile social commerce: The booster for brand loyalty?', Computers in Human Behavior, vol.59, pp.142-154.

Islam, M. A., Cheong, T. W., Yusuf, D. H. M., \& Desa, H . (2011). 'A Study on Generation Y Behaviours at Workplace in Penang', Australian Journal of Basic and Applied Sciences, vol.5, no.11, pp.1802-1812.

Jacobsen, S., \& Barnes, N. G. (2017). 'On Being Social: How Social Identity Impacts Social Commerce for the Millennial Shopper', International Journal of Management Science and Business Administration, vol.3, no.4, pp.38-45.

Juniwati. (2014). 'Influence of Perceived Usefulness, Ease of Use, Risk on Attitude and Intention to Shop Online', European Journal of Business and Management, vol.6, no.27, pp.218228.

Khayati, S., \& Zouaou, S. K. (2013). 'Perceived Usefulness and Use of Information Technology: the Moderating Influences of the Dependence of a Subcontractor towards His Contractor', Journal of Knowledge Management, vol.3, no.6, pp.68-77.

Kline, R. B. (2005). Principles and practice of structural equation modeling, 2nd ed., Guilford, New York.

Kothari, C. R. (1985). Research Methodology: Methods and Techniques: 2nd Ed, John Wiley, Sons Ltd. 
INTERNATIONAL JOURNAL OF ACADEMIC RESEARCH IN BUSINESS AND SOCIAL SCIENCES

Vol. 10, No. 9, 2020, E-ISSN: 2222-6990 @ 2020 HRMARS

Kwek, C. L., Lau, T. C., \& Tan, H. P. (2010). 'The Effects of Shopping Orientations, Online Trust and Prior Online Purchase Experience toward Customers' Online Purchase Intention', International Business Research, vol.3, no.3, pp.63-76.

Lee, G. G., \& Lin, H. F. (2005). 'Customer perceptions of e-service quality in online shopping', International Journal of Retail \& Distribution Management, vol.33, no.2, pp.161-176.

Lee, H. H., Kim, J. H., \& Fiore, A. M. (2006). 'The role of the Technology Acceptance Model in explaining effects of image interactivity technology on consumer responses', International Journal of Retail \& Distribution Management, vol.34, no.8, pp.621-644.

Makmor, N., Alam, S. S., \& Aziz, N. (2018). 'Social Support, Trust and Purchase Intention in Social Commerce Era', International Journal of Supply Chain Management, vol.7, no.5, pp.572-581.

Mayer, R. C., Davis, J. H., \& Schoorman, F. D. (1995). 'An Integrative Model of Organization Trust', The Academy of Management Review, vol.20, no.3, pp.709-734.

McShane, B., Gal, D., Gelman, A., Robert, C., \& Tackett, J. L. (2019). 'Abandon Statistical Significance', The American Statistician, vol.73, no.1, pp.235-245.

Moreno, F., Lafuente, J., Carreon, F., \& Moreno, S. (2017). 'The Characterization of the Millennials and Their Buying Behavior', International Journal of Marketing Studies, vol.9, no.5, pp.135144.

Moslehpour, M., Pham, V. K., Wong, W. K., \& Bilgicli, I. (2018). 'e-Purchase Intention of Taiwanese Consumers: Sustainable Mediation of Perceived Usefulness and Perceived Ease of Use', Risk Measures with Application in Finance and Economics, vol.10, no.1, pp.234-250.

Nunnally, J., \& Bernstein, I. (1994). Psychometric theory (3rd ed.), McGraw-Hill, New York.

Ordun, G. (2015). 'Millennial (Gen Y) Consumer Behavior, Their Shopping Preferences and Perceptual Maps Associated With Brand Loyalty', Canadian Social Science, vol.11, no.4, pp.40-55.

Pavlou, P. A. (2003). 'Consumer Acceptance of Electronic Commerce: Integrating Trust and Risk with the Technology Acceptance Model', International Journal of Electronic Commerce, vol.7, no.3, pp.101-134.

Pearson, J. M., Pearson, A., \& Green, D. (2007). 'Determining the importance of key criteria in web usability', Management Research News, vol.30, no.11, pp.816-828.

Radner, R., \& Rothschild, M . (1975). 'On the allocation of effort', Journal of Economic Theory, vol.10, no.3, pp.358-376.

Rahman, M. K., Al-Mamum, A., Jalil, A., \& Robel, S. D. (2014). 'Factors Influencing Malaysian Consumers' Intention Towards E-shopping', Journal of Applied Sciences, vol.14, no.18, pp.2119-2128.

Reibstein, D. (2002). 'What Attracts Customers to Online Stores, and What Keeps Them Coming Back?', Journal of the Academy of Marketing Science, vol.30, no.4, pp.465-473.

Sarika, K., Preeti, S., Shilpy, S., \& Sukanya, S. (2016). 'A Study of Adoption Behavior for Online Shopping: An Extension of Tam Model', International Journal Advances in Social Science and Humanities, vol.4, no.7, pp.11-22.

Saunders, M., Lewis, P., \& Thornhill, A . (2016). Research Method for Business Students Seventh edition, Edinburgh Gate, Harlow: Pearson Education Limited.

Sin, S. S., Nor, K., \& Al-Agaga, A. M. (2012). 'Factors Affecting Malaysian young consumers' online purchase intention in social media websites', Procedia- Social and Behavioural Sciences, vol.40, pp.326-333. 
INTERNATIONAL JOURNAL OF ACADEMIC RESEARCH IN BUSINESS AND SOCIAL SCIENCES

Vol. 10, No. 9, 2020, E-ISSN: 2222-6990 @ 2020 HRMARS

Sturiale, L., \& Scuderi, A. (2013). 'Evaluation of social media actions for the agrifood system, Procedia Technology', Procedia Technology, vol. 8, pp. 200-208.

Swanson, R., \& Holton, E . (2005). Research in Organization, Berrett-Koehler Publishers, San Francisco

Tariq, N., \& Eddaoudi, B. (2009). 'Assessing the effect of trust and security factors on consumers' willingness for online shopping among the urban moroccans', International Journal of Business Science and Applied Management, vol.2, no.1, pp.17-32.

Twenge, J. M., Campbell, S. M., Hoffman, B. J., \& Lance, C. E. (2010). 'Generational Differences in Work Values: Leisure and Extrinsic Values Increasing, Social and Intrinsic Values Decreasing', Journal of Management, vol.36, no.5, pp.1117-1142.

Yan, B., Zhong, Y., \& Dou, Y. F . (2015). 'Effect of social commerce factors on user purchase behavior: An empirical investigation from renren.com', International Journal of Information Management, vol.35, no.5, pp.538-550. 